\title{
PENGARUH ASAL BIJI KAKAO DAN LAMA CONCHING TERHADAP KARAKTERISTIK SENSORI COKELAT HITAM DENGAN PENDEKATAN DISCRETE TIME INTENSITY
}

\author{
Effect of Cocoa Bean Origin and Length of Conching on Characteristics \\ Sensory of Dark Chocolate Approach Discrete Time Intensity
}

\author{
La Ode Muhammad Fajrul Azhar ${ }^{1}$, Kiki Fibrianto ${ }^{1 *}$, Sukrisno Widyotomo ${ }^{2}$, Harijono ${ }^{1}$ \\ ${ }^{1}$ Jurusan Teknologi Hasil Pertanian - Fakultas Teknologi Pertanian - Universitas Brawijaya \\ Jalan Veteran, Malang 65145 \\ ${ }^{2}$ Pusat Penelitian Kopi dan Kakao Indonesia \\ Jl. P.B. Sudirman No. 90 - Jember 68118 \\ *Penulis Korespondensi: email: kiki.fibrianto@ub.ac.id
}

\begin{abstract}
ABSTRAK
Kakao merupakan salah satu komoditas andalan di Indonesia. Pengolahan kakao menjadi cokelat merupakan salah satu cara untuk meningkatkan nilai tambah kakao. Tujuan penelitian ini adalah mengetahui pengaruh asal biji kakao dan lama conching terhadap karakteristik sensori cokelat hitam. Cokelat dibuat dengan menggunakan Rancangan Acak Kelompok (RAK) dengan dua faktor yaitu asal biji kakao (100\% biji kakao fermentasi Jember, 100\% biji kakao fermentasi Sulawesi Tenggara, 50\% biji kakao fermentasi Jember $+50 \%$ biji kakao nonfermentasi Sulawesi Tenggara, dan 50\% biji kakao fermentasi Sulawesi Tenggara $+50 \%$ biji kakao nonfermentasi Sulawesi Tenggara) dan lama conching (4, 6, dan 8 jam). Analisa sensori dilaksanakan dengan menggunakan panelis terlatih dengan menggunakan metode discrete time intensity. Hasil analisa menunjukkan bahwa kekerasan dan kekenyalan tertinggi yaitu pada perlakuan $100 \%$ biji kakao fermentasi Jember dengan lama conching 8 jam yaitu 12.6 dan 11.9 pada detik ke-30, kekompakan tertinggi yaitu pada perlakuan $50 \%$ biji kakao fermentasi Sulawesi Tenggara $+50 \%$ biji kakao nonfermentasi Sulawesi Tenggara dengan lama conching 8 jam yaitu 12.4 pada detik ke-30 dan kelengketan yang tertinggi yaitu pada perlakuan $100 \%$ biji kakao fermentasi Jember dengan lama conching 4 jam yaitu 5.9 pada detik ke 120
\end{abstract}

Kata kunci : Cokelat, Discrete Time Intensity, Kakao, Karakteristik Sensori

\begin{abstract}
Cocoa is one of the largest commodities in Indonesia. Processing cocoa into chocolate is a way to increase the added of cocoa value. The purpose of this study was to determine the effect of cocoa bean origin and length of conching on sensory characteristics of dark chocolate. Chocolate was made using a completely randomized block design with factorial design consisting of two factors cocoa bean origin (100\% Jember fermented cocoa beans, 100\% Southeast Sulawesi fermented cocoa beans, 50\% Jember fermented cocoa beans $+50 \%$ Southeast Sulawesi non-fermented cocoa beans and $50 \%$ Southeast Sulawesi fermented cocoa beans $+50 \%$ Southeast Sulawesi non-fermented cocoa beans) and length of conching $(4,6$, and 8 hours). Analysis sensory using trained panelist with discrete time intensity method. The analysis showed that the highest hardness and gumminess at 100\% Jember fermented cocoa beans with length of conching 8 hours is 12.6 and 11.9 at 30 seconds. The highest cohesiveness at $50 \%$ fermented cocoa beans Southeast Sulawesi $+50 \%$ non-fermented cocoa beans from Southeast Sulawesi with length of conching 8 hours is 12.4 at 30 seconds. The highest adhesiveness at 100\% Jember fermented cocoa beans with length of conching 4 hours is 5.9 at 120 seconds
\end{abstract}

Keywords : Cocoa, Chocolate, Discrete Time Intensity, Sensory Characteristics 
Jurnal Teknologi Pertanian Vol. 19 No. 1 [April 2018] 1-14

Pengaruh Asal Biji Kakao dan Lama Conching Terhadap Karakteristik Sensori [Azhar dkk]

\section{PENDAHULUAN}

Kakao (Theobroma cacao L.) merupakan salah satu komoditas perkebunan yang mempunyai peranan penting dalam perekonomian Indonesia khususnya sebagai penyedia lapangan kerja, sumber pendapatan dan sumber devisa negara (Ariyanti et al., 2008; Poppenborg dan Hölscher, 2009; Davit et al., 2013; Suwastika et al., 2015; ). Tahun 2010, Indonesia merupakan negara pengekspor biji kakao terbesar ketiga di dunia dengan produksi biji kering sebesar 550000 ton setelah Pantai Gading dan Ghana dengan produksi biji kering sebesar 1242000 ton dan 662000 ton (Rubiyo dan Siswanto, 2012). Luas areal tanaman kakao di Indonesia pada tahun 2009 mencapai 1587136 ha dengan sentra kakao Indonesia tersebar di Pulau Sulawesi yaitu $63.8 \%$, Sumatera $16.3 \%$, Jawa $5.3 \%$, Nusa Tenggara Timur, Nusa Tenggara Barat dan Bali 4\%, Kalimantan 3.6\% dan Maluku dan Papua 7.1\% (Kementerian Pertanian, 2013).

Sekitar 78.5\% biji kakao di Indonesia di ekspor dalam bentuk kering tanpa proses pengolahan menjadi produk terlebih dahulu merupakan salah satu permasalahan dalam komoditas kakao di Indonesia (Rubiyo dan Siswanto, 2012). Para petani menghendaki proses pembayaran yang lebih cepat tanpa harus menunggu proses pengolahan merupakan penyebab utama sehingga berdampak langsung pada pendapatan petani menjadi berkurang dan kurang berkembangnya industri pengolahan kakao dalam negeri (Munarso, 2016). Pengolahan kakao menjadi produk olahan merupakan salah satu cara meningkatkan nilai tambah kakao dan salah satu produk yang dapat meningkatkan nilai tambah kakao adalah cokelat (Lada et al., 2014).

Cokelat merupakan suspensi partikelpartikel seperti pasta kakao, susu bubuk dan gula yang terdispersi dalam fase kontinyu yaitu lemak kakao (Andrae-Nightingale et al., 2009). Kualitas produk cokelat dipengaruhi oleh struktur, teknik proses dan komposisi bahan (Jovanovic dan Pajin, 2002). Karakteristik bahan baku akan mempengaruhi kualitas dan atribut sensori cokelat (Lee et al., 2002). Kakao sebagai bahan baku utama pembuatan cokelat akan memiliki karakteristik yang berbeda berdasarkan perbedaan daerah tumbuhnya, sehingga perbedaan asal biji kakao akan mempengaruhi produk cokelat yang dihasilkan (Gu et al., 2013; Torres-Moreno et al., 2015; Menezes et al., 2016). Selain itu, proses dalam pembuatan cokelat mempengaruhi kualitas akhir produk cokelat dan salah satu tahapan proses pembuatan cokelat adalah conching. Afoakwa et al. (2007) menyatakan bahwa conching merupakan tahap yang penting untuk menentukan ukuran partikel dan konsistensi suspensi dan viskositas untuk menghasilkan kualitas tekstur dan sensori yang khas.

Cokelat memiliki sifat leleh yang unik yaitu bersifat padat pada suhu ruang dan meleleh pada suhu tubuh (Afoakwa, 2010). Persepsi sensori cokelat ketika meleleh di dalam mulut merupakan suatu fenomena sensoris yang bersifat dinamis dan tidak bersifat statis sehingga intensitas sensori yang dirasakan berubah dari waktu ke waktu (Palazzo et al., 2011). Metode sensoris yang dapat digunakan untuk mengukur dan memperoleh informasi mengenai perubahan atribut sensoris cokelat selama dikonsumsi adalah dengan menggunakan metode time intensity (Afoakwa, 2010).

Analisa sensori dengan metode time intensity digunakan untuk memperoleh profil temporal atribut produk pangan (Morais et al., 2014). Time intensity merupakan suatu metode sensori yang dapat mencatat persepsi dari suatu atribut sensori dan perubahan atribut sensori tersebut ketika bahan makanan tersebut sedang diproses di dalam mulut (Peyvieux dan Dijksterhuis, 2001). Time intensity akan memberikan suatu hubungan antara satu atribut dengan durasi waktu dari atribut tersebut (Afoakwa, 2010). Sehingga dengan penggunaan metode time intensity untuk analisa sensoris cokelat dapat memberikan informasi mengenai perubahan-perubahan pada atribut sensoris cokelat selama dikonsumsi. Beberapa hasil penelitian telah melaporkan penggunaan metode Time intensity untuk menganalisa berbagai jenis bahan pangan seperti roti (de Morais et al., 2013), keju (Pionnier et al., 2004), cokelat (Palazzo et al., 2011; Palazzo dan Bolini, 2014), daging (Lorido et al., 2014), ice cream (Cadena dan Bolini, 2011) dan kopi (Moraes dan Bolini, 2010).

\section{BAHAN DAN METODE}

\section{Bahan}


Bahan yang digunakan dalam penelitian ini untuk pembuatan cokelat adalah biji kakao fermentasi yang telah dikeringkan yang diperoleh dari Pusat Penelitian Kopi dan Kakao Indonesia dan biji kakao fermentasi dan biji kakao nonfermentasi yang telah dikeringkan yang diperoleh dari petani di kecamatan Pondidaha, kabupaten Konawe, Provinsi Sulawesi Tenggara. Biji kakao yang digunakan adalah biji kakao jenis Forastero. Biji kakao kemudian disangrai, dilakukan pemisahan antara kulit dan nib kakao, penghalusan nib kakao dengan menggunakan mesin pemasta kakao untuk mendapatkan pasta kakao dan pengempaan pasta kakao untuk mendapatkan lemak kakao. Pasta kakao dan lemak kakao yang diperoleh digunakan sebagai bahan baku untuk pembuatan cokelat. Bahan baku pembuatan cokelat lainnya adalah susu bubuk full cream, gula halus, vanili, lesitin, dan soda kue.

Bahan yang digunakan untuk analisa cokelat adalah toluen dan heksana. Bahan yang digunakan untuk proses uji sensori adalah asam sitrat murni, asam asetat murni, kafein murni, gula pasir komersial, garam komersial, monosodium glutamat (MSG) komersial, dan air mineral.

\section{Alat}

Alat yang digunakan untuk proses pengolahan biji kakao dan pembuatan cokelat adalah mesin sangrai biji kakao kapasitas 1 kg dengan bahan bakar LPG, mesin desheller (pemisah antara kulit dan nib kakao), mesin pemasta kasar, mesin pengempa pasta kapasitas $1 \mathrm{~kg}$, mesin pencampur dan penghalus ball mill kapasitas $500 \mathrm{~g}$, mesin conching tipe slinder berputar kapasitas 1 kg, kabinet tempering, baskom, pengaduk, timbangan analitik, gunting, sendok, termometer, cetakan cokelat, dan alumunium foil.

Alat yang digunakan untuk uji organoleptik adalah cup plastik bening dengan diameter bawah $3.5 \mathrm{~cm}$, diameter atas $6 \mathrm{~cm}$ dan tinggi $4 \mathrm{~cm}$, gelas ukur $25 \mathrm{ml}$, spatula, beaker glass ukuran $1000 \mathrm{ml}$, nampan, sendok, pisau, dan timbangan analitik (Mettler Toledo tipe Newclassic MF).

\section{Metode}

\section{Rancangan Percobaan}

Pembuatan cokelat dilakukan dengan menggunakan Rancangan Acak Kelompok (RAK) yang terdiri dari 2 faktor. Faktor pertama adalah asal bahan baku biji kakao yang terdiri dari empat taraf yaitu 100\% biji kakao fermentasi Jember, $100 \%$ biji kakao fermentasi Sulawesi Tenggara, 50\% biji kakao fermentasi Jember $+50 \%$ biji kakao nonfermentasi Sulawesi Tenggara dan 50\% biji kakao fermentasi Sulawesi Tenggara $+50 \%$ biji kakao nonfermentasi Sulawesi Tenggara dan faktor kedua adalah lama conching yang terdiri dari tiga taraf yaitu lama conching 4 jam, 6 jam 8 jam. Tahap kedua adalah analisa sensori produk cokelat dengan menggunakan metode discrete time intensity.

\section{Proses Pembuatan Cokelat}

Komposisi bahan baku pembuatan cokelat disajikan pada Tabel 1. Tahapan proses pembuatan cokelat yaitu pasta kakao, lemak kakao, susu bubuk, dan gula halus dicampur dan dihaluskan dengan menggunakan mesin pencampur dan penghalus yaitu ball mill selama 12 jam dengan suhu $50^{\circ} \mathrm{C}$. Bahan yang telah dicampur dan dihaluskan kemudian dimasukkan ke dalam mesin conching. Lama proses conching sesuai dengan perlakuan yang dilakukan yaitu 4 jam, 6 jam dan 8 jam dengan suhu $50^{\circ} \mathrm{C}$. Lesitin dan vanili ditambahkan ke dalam adonan cokelat 2 jam sebelum proses conching berakhir. Pasta cokelat hasil proses conching kemudian ditempering. Tahapan proses tempering pasta cokelat yaitu pasta cokelat didiamkan selama 10 menit pada suhu $33{ }^{\circ} \mathrm{C}$, lalu dipanaskan sampai suhu $50^{\circ} \mathrm{C}$ selama 20 menit, kemudian adonan cokelat didinginkan sampai suhu $33{ }^{\circ} \mathrm{C}$ dan didiamkan selama 10 menit, setelah itu diturunkan lagi suhunya sampai pada suhu $26^{\circ} \mathrm{C}$ didiamkan selama 10 menit. Tahap terakhir dari proses tempering, adonan dipanaskan kembali sampai suhu sekitar 30 ${ }^{\circ} \mathrm{C}$. Proses pencetakan cokelat dilakukan apabila suhu pasta cokelat telah mencapai suhu

Tabel 1. Komposisi bahan baku pembuatan cokelat

\begin{tabular}{lc}
\hline Bahan Baku & Proporsi (g) \\
\hline Pasta cokelat & 390 \\
Lemak kakao & 310 \\
Susu bubuk & 115 \\
Gula halus & 185 \\
Soda kue & 3 \\
Vanili & 1 \\
Lesitin & 3 \\
\hline
\end{tabular}


29-30 ${ }^{\circ} \mathrm{C}$. Cokelat yang telah dimasukkan ke dalam cetakan, kemudian dimasukkan ke dalam kabinet tempering dengan suhu 10 ${ }^{\circ} \mathrm{C}$ selama 60 menit. Adonan cokelat kemudian dilepaskan dari cetakan dan di tempering di ruangan dengan air conditioner selama satu hari pada suhu $25{ }^{\circ} \mathrm{C}$ sebelum dilakukan pengemasan. Cokelat dikemas dengan menggunakan alumunium foil dan kembali ditempering dalam ruangan yang memiliki air conditioner selama 7 hari pada suhu $25^{\circ} \mathrm{C}$.

\section{Analisa Sensori}

Analisa sensori dilakukan dengan menggunakan panelis terlatih yang terdiri dari beberapa tahapan yaitu pemilihan calon panelis, seleksi panelis, pelatihan panelis dan pengujian sensoris cokelat dengan menggunakan metode discrete time intensity.

\section{Pemilihan Calon Panelis}

Pemilihan calon panelis diseleksi melalui pengisian kuisioner dan wawancara terhadap beberapa hal yang berhubungan dengan ketersediaan sebagai calon panelis dan kesehatan. Calon panelis yang dipilih untuk menjadi panelis terlatih dilakukan pada 20 orang yang terdiri dari 10 orang laki-laki dan 10 orang perempuan. Belščak-Cvitanović et al. (2015) menyatakan syarat calon panelis dipilh berdasarkan kriteria antara lain tidak ada keengganan, alergi dan intoleransi terhadap cokelat, bukan seorang perokok, berusia diantara 22-45 tahun, kemampuan persepsi yang normal, tidak kecanduan cokelat, tersedia untuk semua sesi, serta tertarik untuk mengikuti uji sensoris.

\section{Seleksi Panelis}

Calon panelis yang memenuhi persyaratan sebagai panelis mengikuti uji seleksi sensori untuk mengetahui kondisi sensori panelis. Sampel yang digunakan untuk uji pengenalan sebagai uji seleksi sensori berdasarkan ES ISO 22935-1:2012. Uji ambang pengenalan digunakan untuk mengetahui apakah panelis dapat mengenali sampel rasa dasar yang disajikan. Melalui metode ini panelis diminta mendeskripsikan secara singkat tentang sampel rasa yang disajikan, sehingga dapat diketahui bahwa indra perasa panelis bekerja dengan baik. Rasa dasar yang disajikan dalam penelitian ini yaitu sampel uji rasa manis $1 \%(\mathrm{~b} / \mathrm{v})$ yang berasal dari larutan gula pasir, rasa asam $0.03 \%(\mathrm{~b} / \mathrm{v})$ yang berasal dari larutan asam sitrat murni, rasa asin $0.2 \%(\mathrm{~b} / \mathrm{v})$ yang berasal dari larutan garam, rasa pahit $0.03 \%(\mathrm{~b} / \mathrm{v})$ yang berasal dari larutan kafein murni, rasa umami $0.06 \%$ (b/v) yang berasal dari larutan monosodium glutamat dan plain (hambar) yang berasal dari air mineral tanpa tambahan apapun. Sebanyak $25 \mathrm{ml}$ larutan sampel rasa dasar diletakkan di dalam cup plastik bening. Sebelum dan sesudah melakukan pengujian rasa dasar panelis diharuskan mengkonsumsi palate cleanser yaitu air mineral untuk menetralkan indra perasa.

\section{Pelatihan Panelis \\ Uji Ambang Mutlak (Threshold Test)}

Pengukuran uji ambang mutlak didasarkan pada tingkat rangsangan yang dapat menghasilkan respon benar dari 50\% panelis. Pengukuran uji ambang mutlak dilakukan dengan menggunakan uji segitiga. Sampel yang digunakan untuk uji ambang mutlak adalah empat rasa dasar yaitu manis, asam, asin, dan pahit. Penentuan konsentrasi berdasarkan standar ES ISO 22935-1:2012. Sampel rasa manis terdiri dari konsentrasi $0.5 \%(\mathrm{~b} / \mathrm{v}), 1 \%(\mathrm{~b} / \mathrm{v})$, dan $1.5 \%(\mathrm{~b} / \mathrm{v})$ yang berasal dari larutan gula pasir komersial. Sampel rasa asam berasal dari larutan asam sitrat murni dengan konsentrasi $0.01 \%(b / v)$, $0.03 \%$ (b/v), dan $0.05 \%$ (b/v). Larutan garam $(\mathrm{NaCl})$ komersial digunakan sebagai sampel rasa asin dengan konsentrasi $0.1 \%(\mathrm{~b} / \mathrm{v})$, $0.15 \%(\mathrm{~b} / \mathrm{v})$, dan $0.2 \%(\mathrm{~b} / \mathrm{v})$. Sampel rasa pahit berasal dari larutan kafein murni yang terdiri dari konsentrasi $0.01 \%(\mathrm{~b} / \mathrm{v}), 0.03 \%$ $(\mathrm{b} / \mathrm{v})$, dan $0.05 \%(\mathrm{~b} / \mathrm{v})$. Pembanding yang digunakan adalah air. Sampel yang disajikan berjumlah tiga dengan dua sampel yang sama dan satu sampel yang berbeda. Ketiga sampel disajikan dengan kombinasi tiga digit angka. Sampel untuk uji ambang mutlak diletakkan di dalam cup plastik bening.

Uji ambang mutlak dilakukan dengan menggunakan sampel dan blanko. Sampel merupakan larutan yang memiliki senyawa rasa dasar, sedangkan blanko merupakan larutan yang tidak memiliki senyawa rasa dasar. Blanko yang digunakan adalah air mineral. Sampel yang disajikan terdiri dari satu sampel dan dua blanko dan satu blanko dan dua sampel. Pada pelaksanaannya, panelis diharuskan mengkonsumsi palate cleanser berupa air mineral di setiap sebelum dan sesudah mencoba sampel untuk menetralkan indra perasa.

Pelatihan uji ambang mutlak dilakukan dengan menggunakan konsentrasi 
meningkat (ascending concentration) dan konsentrasi menurun (descending concentration). Konsentrasi meningkat adalah kondisi di mana sampel dimulai dengan konsentrasi terendah dan diakhiri dengan konsentrasi tertinggi, sedangkan konsentrasi menurun dimana sampel disajikan dari konsentrasi tertinggi terlebih dahulu dan dilanjutkan dengan konsentrasi terendah. Setiap panelis mendapatkan konsentrasi meningkat dan konsentrasi menurun dan mendapatkan sampel yang disajikan yang terdiri dari satu sampel dengan dua blanko dan dua sampel dengan satu blanko. Panelis yang pada pengulangan pertama mendapatkan konsentrasi meningkat dengan dua sampel dan satu blanko maka pada pengulangan kedua mendapatkan konsentrasi menurun dengan satu sampel dan dua blanko sedangkan panelis yang pada pengulangan pertama mendapatkan konsentrasi menurun dengan satu sampel dan dua blanko maka pada pengulangan kedua mendapatkan konsentrasi meningkat dengan dua sampel dan satu blanko.

\section{Pelatihan Uji Discrete Time intensity}

Pelatihan panelis untuk uji discrete time intensity berfokus pada pengenalan metode, prosedur atau instruksi pengujian dan alat yang digunakan (ASTM, 1997). Pelatihan panelis untuk uji discrete time intensity dilakukan sebanyak satu kali. Tahapan pelatihan panelis dilakukan dalam tiga tahap yaitu pengenalan metode, prosedur dan protokol pengujian; pengenalan semua alat yang digunakan dan semua tugas panelis yang harus dilakukan dalam pengujian dan melatih panelis secara langsung dengan sampel (Peyvieux dan Dijksterhuis, 2001).

Pengenalan metode dan prosedur pengujian dilakukan dengan cara memberikan penjelasan metode dengan menyajikan lembar prosedur atau instruksi pengujian discrete time intensity kepada panelis (Novianti, 2015). Pada tahap ini juga dijelaskan tentang sampel yang digunakan pada saat pengujian dan dijelaskan beberapa istilah pada pengujian discrete time intensity yaitu Imax (intensitas maksimum dari respon time intensity), Tmax (waktu untuk mencapai intensitas maksimum), Ttot (total durasi waktu respon time intensity dari dari awal diproses secara oral sampai sensasi sensori hilang), dan AUC (Area Under Curve) yaitu jumlah total area dibawah kurva time intensity yang menya- takan total intensitas atribut sensori pada seluruh periode dari awal sampel masuk ke dalam mulut hingga waktu berakhir (Morais et al., 2014). Langkah selanjutnya adalah pengenalan panelis dengan semua alat dan semua tugas panelis selama pengujian dan dilakukan dengan mendemonstrasikan proses pengujian (Novianti, 2015).

Tahap terakhir adalah melatih panelis secara langsung menggunakan sampel cokelat (Novianti, 2015). Pada tahapan ini panelis juga melakukan simulasi pengujian dan pelatihan untuk membedakan parameter-parameter tekstur cokelat yang diamati meliputi kekerasan (energi yang diperlukan untuk menekan suatu substansi dengan menggunakan gigi geraham pada bahan yang bersifat solid atau dengan di antara lidah dan langit-langit pada bahan pangan yang bersifat semi-solid), kekompakan (parameter tekstur yang mengindikasikan kekuatan ikatan internal yang menyusun atau membentuk tekstur suatu bahan pangan), kelengketan (tenaga yang diperlukan untuk menghilangkan material yang menempel dipermukaan di dalam mulut (terutama langit-langit) selama proses memakan suatu makanan) dan kekenyalan (energi yang diperlukan untuk menghancurkan suatu bahan pangan yang bersifat semi solid ke suatu kondisi siap untuk ditelan) (Szczesniak, 2002). Analisa tekstur kekerasan dilakukan dengan meletakkan sampel cokelat di atas lidah, ditekan sekali dengan langit-langit, kekompakan dilakukan dengan meletakkan sampel di atas lidah kemudian sampel ditekan dengan lidah dengan langit-langit sebanyak lima kali, kelengketan dilakukan dengan meletakkan sampel di atas lidah, diangkat secara perlahan dan ditekan dengan langit-langit mulut tanpa menekan sampel dan kekenyalan dilakukan dilakukan dengan meletakkan sampel di antara lidah dan langit-langit mulut dan sampel ditekan antara lidah dan langit-langit (Brighenti et al., 2008).

\section{Analisis Sensori Cokelat}

Analisis sensori cokelat dilakukan dengan menggunakan metode discrete time intensity. Jumlah panelis yang mengikuti tahap analisa sensori cokelat adalah 10 orang yang terdiri dari 3 orang laki-laki dan 7 orang perempuan. Sampel yang disajikan diletakkan dalam cup plastik bening dan diberikan kode kombinasi tiga angka. Uji discrete time intensity dilakukan dengan menggunakan 
Jurnal Teknologi Pertanian Vol. 19 No. 1 [April 2018] 1-14

Pengaruh Asal Biji Kakao dan Lama Conching Terhadap Karakteristik Sensori [Azhar dkk]

Tabel 2. Parameter-parameter kurva TI tekstur kekerasan

\begin{tabular}{ccc}
\hline Faktor & Parameter & $p$-value \\
\hline \multirow{3}{*}{ Sampel } & $\mathrm{I}_{\max }$ & $0.000^{*}$ \\
& $\mathrm{~T}_{\text {tot }}$ & $0.038^{*}$ \\
& $\mathrm{~T}_{\max }$ & 0.443 \\
& AUC & $0.000^{*}$ \\
\hline
\end{tabular}

Keterangan: $\left({ }^{*}\right)=$ berpengaruh nyata. Nilai $p$-value $<0.05$ menunjukkan pengaruh yang nyata

Tabel 4. Parameter-parameter kurva TI tekstur kelengketan

\begin{tabular}{ccc}
\hline Faktor & Parameter & $p$-value \\
\hline \multirow{3}{*}{ Sampel } & $\mathrm{I}_{\max }$ & 0.482 \\
& $\mathrm{~T}_{\text {tot }}$ & $0.016^{*}$ \\
& $\mathrm{~T}_{\text {max }}$ & 0.277 \\
& AUC & $0.019^{*}$ \\
\hline
\end{tabular}

Keterangan: $\left(^{*}\right)=$ berpengaruh nyata. Nilai $p$-value $<0.05$ menunjukkan pengaruh yang berbeda nyata
Tabel 3. Parameter-parameter kurva TI tekstur kekompakan

\begin{tabular}{ccc}
\hline Faktor & Parameter & $p$-value \\
\hline & $\mathrm{I}_{\max }$ & $0.000^{*}$ \\
Sampel & $\mathrm{T}_{\text {tot }}$ & $0.026^{*}$ \\
& $\mathrm{~T}_{\max }$ & 0.443 \\
& AUC & $0.007^{*}$ \\
\hline Keterangan: $\left.{ }^{*}\right)=$ berpengaruh nyata. Nilai $p$-value \\
$<0.05$ menunjukkan pengaruh yang berbeda nyata
\end{tabular}

Tabel 5. Parameter-parameter kurva TI tekstur kekenyalan

\begin{tabular}{ccc}
\hline Faktor & Parameter & $p$-value \\
\hline \multirow{4}{*}{ Sampel } & $\mathrm{I}_{\max }$ & $0.009^{*}$ \\
& $\mathrm{~T}_{\text {tot }}$ & $0.047^{*}$ \\
& $\mathrm{~T}_{\max }$ & 1.000 \\
& AUC & $0.000^{*}$
\end{tabular}

Keterangan: $\left(^{*}\right)=$ berpengaruh nyata. Nilai $p$-value $<0.05$ menunjukkan pengaruh yang berbeda nyata

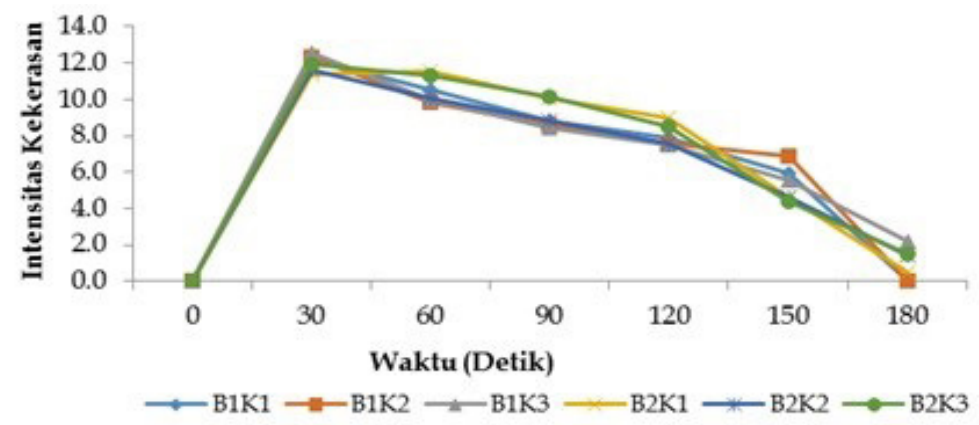

(A)

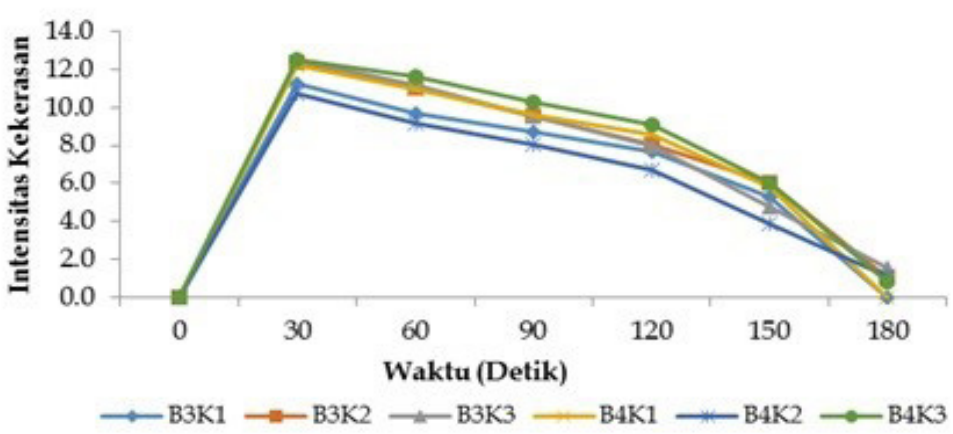

(B)

Gambar 1. Grafik intensitas tekstur kekerasan cokelat. B1 (100\% biji kakao fermentasi Jember); B2 (100\% biji kakao fermentasi Sulawesi Tenggara); B3 (50\% biji kakao nonfermentasi Sulawesi Tenggara $+50 \%$ biji kakao fermentasi Jember); B4 (50\% biji kakao nonfermentasi Sulawesi Tenggara $+50 \%$ biji kakao fermentasi Sulawesi Tenggara); K1 (lama conching 4 jam); K2 (lama conching 6 jam); K3 (lama conching 8 jam) 
Rancangan Acak Kelompok (RAK). Setiap panelis diberikan empat sampel cokelat setiap hari. Setiap satu sampel cokelat dianalisa empat parameter tekstur sehingga setiap panelis mendapatkan 16 sampel setiap pengujian. Setiap panelis mendapatkan sampel dengan berat $3 \mathrm{~g}$ dengan ukuran panjang $2 \mathrm{~cm}$, lebar $2 \mathrm{~cm}$ dan tinggi $1 \mathrm{~cm}$. Parameter tekstur cokelat yang dianalisis adalah kekerasan, kekompakan, kelengketan, dan kekenyalan. Analisis dilakukan dalam dua kali ulangan untuk setiap sampel pada hari yang berbeda. Sebelum dan sesudah menguji tiap sampel, panelis diharuskan mengkonsumsi palate cleanser yang disediakan yaitu air mineral hangat dengan suhu $40-45{ }^{\circ} \mathrm{C}$ untuk menetralkan indra perasa. Panelis menerima form pengujian atribut tekstur yang di dalamnya terdapat poin-poin waktu (30 detik, 60 detik, 90 detik, 120 detik, 150 detik, dan 180 detik) dan memberikan respon sampel setiap 30 detik sampai dengan detik ke 180 pada form garis tanpa skala (unstructured scale) sepanjang $15 \mathrm{~cm}$ pada tiap detik tersebut.

\section{Analisis Data}

Analisis data dilakukan dengan menggunakan Microsoft Excel 2010 dan Minitab 16. Data hasil pengamatan analisa sensori cokelat dengan metode discrete time intensity dianalisa dengan menggunakan analisa non parametrik yaitu Friedman Test.

\section{HASIL DAN PEMBAHASAN}

\section{Atribut Tekstur Kekerasan}

Kekerasan merupakan karakteristik primer tekstur bahan pangan (AndraeNightingale et al., 2009). Kekerasan secara sensoris didefinisikan sebagai energi yang diperlukan untuk menekan suatu substansi dengan menggunakan gigi geraham pada bahan yang bersifat solid atau dengan di antara lidah dan langit-langit pada bahan pangan yang bersifat semi-solid (Szczesniak, 2002).

Hasil analisa sensori tekstur cokelat dengan menggunakan metode discrete time intensity dan parameter-parameter dari kurva TI pada atribut tekstur kekerasan cokelat dan disajikan pada Tabel 2 dan Gambar 1. Grafik intensitas kekerasan cokelat menunjukkan bentuk kurva yang mengalami penurunan.
Intensitas kekerasan yang tertinggi pada semua sampel diperoleh pada detik ke-30 yaitu pada perlakuan $100 \%$ biji kakao fermentasi Jember dengan lama conching 8 jam yaitu 12.6 dan tingkat kekerasan cokelat terus mengalami penurunan sampai dengan detik ke-180. Terjadinya penurunan tingkat kekerasan cokelat selama dikonsumsi disebabkan oleh cokelat yang mulai meleleh di dalam mulut. Cokelat yang mulai meleleh ketika di dalam mulut disebabkan oleh lemak kakao sebagai fase kontinyu akan mulai meleleh disebabkan temperatur atau panas tubuh. Ziegler et al. (2001) menyatakan bahwa proses cokelat meleleh di dalam mulut disebabkan karakteristik lemak sebagai fase kontinyu. Temperatur yang berhubungan dengan proses transisi seperti pelelehan akan mengubah struktur suatu bahan pangan selama proses pengunyahan, karena selama proses ini suhu akan memulai proses modifikasi makanan yang mana akan mengubah persepsi tekstur selama proses oral (Pascua et al., 2013).

Proses cokelat meleleh di dalam mulut merupakan suatu proses dinamis yang melibatkan fase transisi dari kondisi padat pada suhu ruang menjadi suatu suspensi padat yang halus pada suhu tubuh (Shah et al., 2010). Cokelat ketika dikonsumsi akan meleleh di dalam mulut, bercampur dengan saliva dan berubah fase (Afoakwa et al., 2007). Cokelat yang meleleh pada suhu tubuh mengindikasikan bahwa kemungkinan kristal lemak kakao berada dalam bentuk $\mathrm{V}$. Bentuk V merupakan bentuk lemak kakao yang paling stabil dan diperoleh dari proses tempering dan memiliki titik leleh sekitar $34{ }^{\circ} \mathrm{C}$ (Fernandez et al., 2013). Lemak kakao yang berada dalam bentuk $\mathrm{V}$ memiliki titik leleh sekitar suhu oral manusia yaitu 34 ${ }^{\circ} \mathrm{C}$ sehingga ketika cokelat masuk ke dalam mulut menyebabkan cokelat mulai meleleh. Afoakwa et al. (2007) yang menyatakan bahwa sifat organoleptik cokelat sangat bergantung pada karakteristik fase kontinyu yaitu lemak kakao. Semakin lama proses oral cokelat berlangsung, tingkat kekerasan cokelat semakin menurun dan semakin mereduksi ukuran partikel cokelat. Ukuran partikel yang semakin kecil, akan meningkatkan luas permukaan untuk transfer panas karena pecahnya formasi partikel-partikel cokelat sehingga proses pelelehan cokelat menjadi semakin signifikan. Shah et al. (2010) menyatakan bahwa kekerasan cokelat dapat secara efektif digunakan untuk memprediksi melt- 
ing time cokelat selama dikonsumsi. Faktorfaktor lain seperti polimorfisme lemak kakao yang dibentuk selama proses tempering dan suhu pendinginan juga berkontribusi terhadap sifat-sifat leleh cokelat (Ziegler et al., 2001).

\section{Atribut Tekstur Kekompakan}

Kekompakan merupakan karakteristik primer tekstur bahan pangan (Andrae Nightingale et al., 2009). Kekompakan secara sensoris didefinisikan sebagai derajat penahan bahan terhadap deformasi suatu substansi atau bahan pangan ditekan dengan menggunakan gigi sebelum bahan pangan tersebut hancur (Szczesniak, 2002).

Hasil analisa sensori tekstur cokelat dengan menggunakan metode discrete time intensity dan parameter-parameter dari kurva TI pada atribut tekstur kekompakan cokelat dan disajikan pada Tabel 3 dan Gambar 2. Grafik intensitas kekompakan cokelat menunjukkan bentuk kurva yang mengalami penurunan. Intensitas kekompakan yang tertinggi diperoleh pada detik ke-30 yaitu pada perlakuan $50 \%$ fermentasi biji kakao Sulawesi Tenggara $+50 \%$ nonfermentasi biji kakao Sulawesi Tenggara dengan lama conching 8 jam yaitu 12.4 dan tingkat kekompakan cokelat terus mengalami penurunan sampai dengan detik ke-180. Menurunnya intensitas kekompakan disebabkan oleh cokelat yang mulai meleleh ketika sampel cokelat masuk ke dalam mulut panelis karena melelehnya cokelat mengawali pengaruh yang signifikan terhadap perubahan fase perubahan fase cokelat. Cokelat yang mulai meleleh akan mereduksi ukuran-ukuran partikel yang mana dengan peningkatan luas permukaan untuk transfer panas karena pemecahan partikel, maka proses pelelehan cokelat menjadi lebih signifikan. Cokelat yang meleleh dan kontak atau bercampur dengan saliva akan menghasilkan pembentukan bertahap dari fase cair bolus. Proses pemecahan cokelat melibatkan gigi dan lidah, temperatur fisiol-

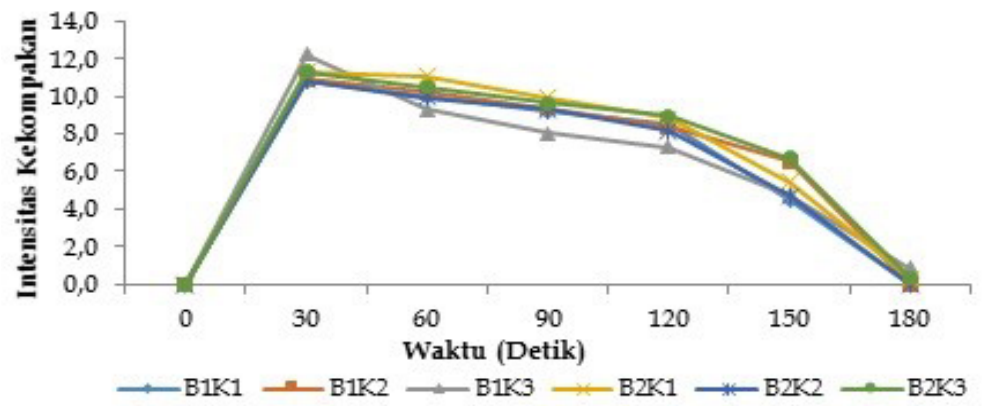

(A)

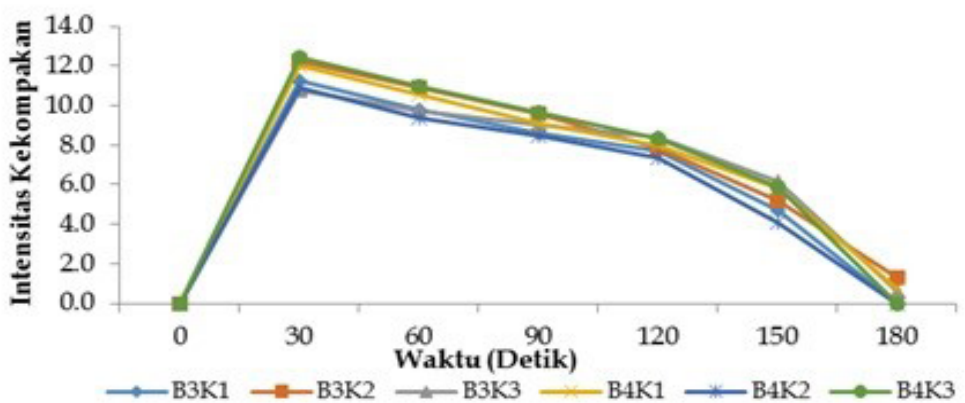

(B)

Gambar 2. Grafik intensitas tekstur kekompakan cokelat. B1 (100\% biji kakao fermentasi Jember); B2 (100\% biji kakao fermentasi Sulawesi Tenggara); B3 (50\% biji kakao nonfermentasi Sulawesi Tenggara $+50 \%$ biji kakao fermentasi Jember); B4 (50\% biji kakao nonfermentasi Sulawesi Tenggara $+50 \%$ biji kakao fermentasi Sulawesi Tenggara); K1 (lama conching 4 jam); K2 (lama conching 6 jam); K3 (lama conching 8 jam) 


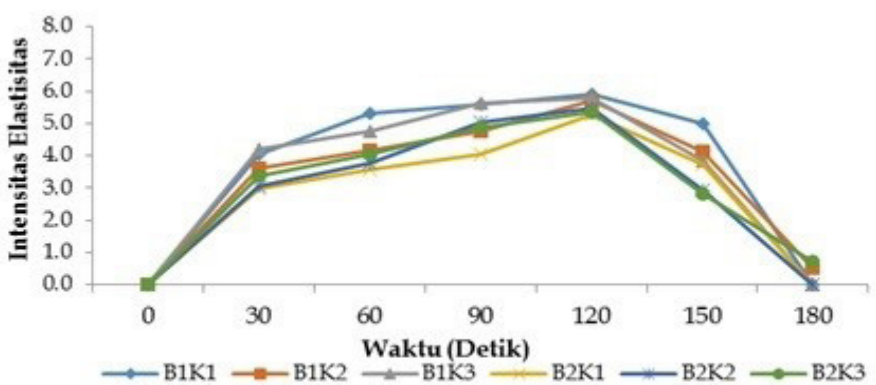

(A)

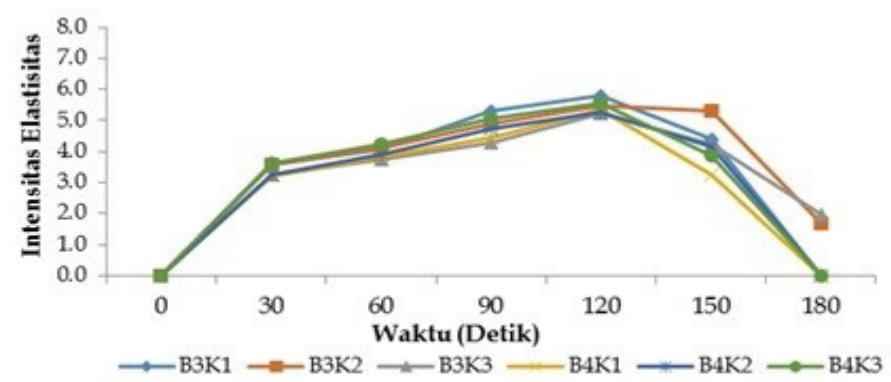

(B)

Gambar 3. Grafik intensitas tekstur kelengketan cokelat. B1 (100\% biji kakao fermentasi Jember); B2 (100\% biji kakao fermentasi Sulawesi Tenggara); B3 (50\% biji kakao nonfermentasi Sulawesi Tenggara $+50 \%$ biji kakao fermentasi Jember); B4 (50\% biji kakao nonfermentasi Sulawesi Tenggara $+50 \%$ biji kakao fermentasi Sulawesi Tenggara); K1 (lama conching 4 jam); K2 (lama conching 6 jam); K3 (lama conching 8 jam)

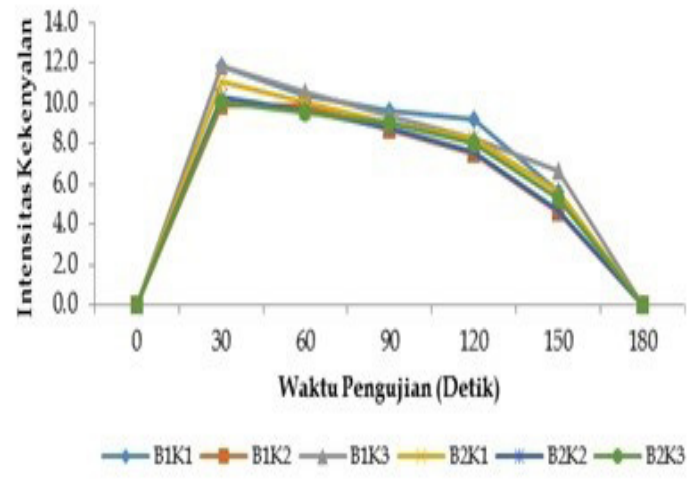

(A)

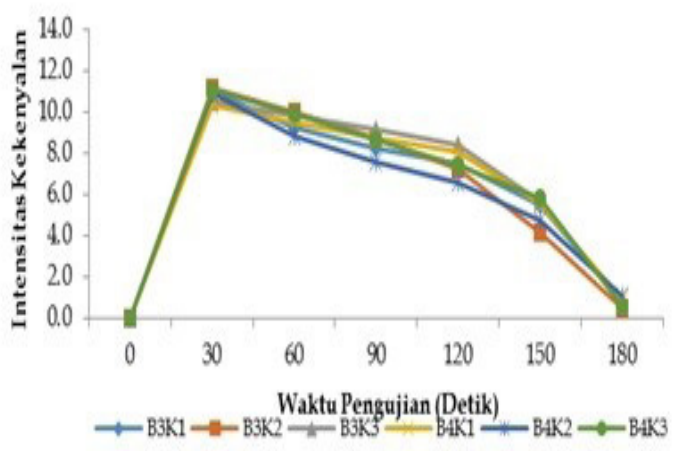

(B)

Gambar 4. Grafik intensitas tekstur kekenyalan cokelat. B1 (100\% biji kakao fermentasi Jember); B2 (100\% biji kakao fermentasi Sulawesi Tenggara); B3 (50\% biji kakao nonfermentasi Sulawesi Tenggara $+50 \%$ biji kakao fermentasi Jember); B4 (50\% biji kakao nonfermentasi Sulawesi Tenggara $+50 \%$ biji kakao fermentasi Sulawesi Tenggara); K1 (lama conching 4 jam); K2 (lama conching 6 jam); K3 (lama conching 8 jam) 
ogis rongga mulut dan kontak dengan saliva menyebabkan melelehnya lemak pada permukaan cokelat. Fragmentasi yang dihasilkan dalam pembentukan permukaan yang baru sebagai partikel yang telah mengalami reduksi ukuran. Faktor ini juga akan menghasilkan pembentukan kumpulan bolus kohesiv yang mengandung sampel cokelat dalam bentuk semi-solid. Kumpulan bolus tersebut mengandung sebagian padatan dan cokelat yang meleleh, partakel-partikel yang bersifat semi-solid akan berikatan satu sama lain secara kohesiv karena permukaan cokelat yang mengandung lemak dan fase cair (campuran lemak cokelat dan saliva).

Kekompakan merupakan sifat-sifat yang empiris yang dalam penentuannya sering menggunakan Texture Profile Analysis (TPA) melalui tes kompresi (Ishihara et al., 2011; de Ávila et al., 2014; Paula et al., 2014; Wu et al., 2014). Analisa pengujian kekompakan merupakan hal yang penting dalam mempelajari sifat-sifat bolus dan proses deformasi suatu bahan pangan (Yoshimine et al., 2008). Salah satu hal yang harus diperhatikan dalam pengukuran kekompakan dengan menggunakan instrumen dapat tidak terdapat hubungan secara langsung dengan sifat sensori yang dirasakan secara langsung terutama disebabkan oleh struktur bahan pangan, komposisi dan interaksi fisikokimia yang berhubungan dengan bolus suatu bahan pangan (Ishihara et al., 2011; Bornhorst et al., 2014; Kikuchi et al., 2017; Rizo et al., 2018). Gaikwad (2012) menyatakan bahwa beberapa faktor seperti perbedaan dalam komposisi dan sifat-sifat fisik berhubungan dengan perbedaan dalam proses pemecahan dan fase transformasi, banyaknya bolus yang dibasahi oleh saliva, ukuran partikel dan jumlah lemak dalam bolus pada saat proses di dalam mulut berperan penting dalam mempengaruhi kekompakan cokelat.

\section{Atribut Tekstur Kelengketan}

Kelengketan merupakan karakteristik primer tekstur bahan pangan (AndraeNightingale et al., 2009). Kelengketan secara sensoris didefinisikan sebagai tenaga yang diperlukan untuk menghilangkan material yang menempel di mulut (terutama langitlangit) selama proses memakan suatu makanan (Szczesniak, 2002).

Hasil analisa sensori tekstur cokelat dengan menggunakan metode discrete time intensity dan parameter-parameter dari kurva TI pada atribut tekstur kelengketan cokelat dan disajikan pada Tabel 4 dan Gambar 3. Grafik intensitas kelengketan pada seluruh sampel cokelat menunjukkan bentuk kurva yang mengalami peningkatan sejak detik ke-0 dan mencapai puncak intensitas tertinggi pada detik ke-120 yaitu pada perlakuan $100 \%$ biji kakao fermentasi Jember dengan lama conching 4 jam yaitu sebesar 5.9 dan mengalami penurunan pada detik ke150 sampai detik ke-180. Kelengketan merupakan karakteristik tekstur yang bergantung pada sifat-sifat suatu bahan pangan dan karakteristik saliva yang dapat dideskripsikan sebagai hasil dari tenaga eksternal yang disebabkan oleh gaya tarik menarik di antara bolus dan permukaan rongga mulut (Peyron et al., 2011). Kelengketan yang dirasakan oleh panelis diduga disebabkan oleh faktor kandungan susu dan gula yang terdapat dalam cokelat. Adesi dan dan kemampuan untuk mengikat air oleh partikel-partikel susu dan sifat higroskopik dari gula meningkatkan potensi mengikat pada permukaan dan agglomerasi yang pada akhirnya akan meningkatkan kelengketan ketika cokelat yang telah meleleh kontak dengan saliva (Sanchez dan Perez, 2012). Afoakwa et al. (2007) menyatakan bahwa ketika cokelat meleleh di dalam mulut, fase kontinyu yaitu lemak kakao akan bercampur dengan saliva yang kemudian akan melarutkan gula. Kelengketan merupakan atribut yang kompleks dan terjadi oleh kombinasi faktor-faktor yang menentukan yaitu adhesi (sifat reologi dan sifat permukaan) dan lubrikasi (pengaruh dari saliva) suatu bahan pangan (Pascua et al., 2013). Peyron et al. (2011) menyatakan bahwa sifat kelengkatan mungkin tergantung pada sifatsifat bahan pangan dan karakteristik saliva.

Atribut kelengketan cokelat yang dirasakan oleh panelis merupakan sensasi dari lemak yang dirasakan yang bercampur dengan saliva yang menempel di mulut terutama pada bagian langit-langit mulut (Gaikwad, 2012). Chale-Rush et al. (2007) menyatakan bahwa sensasi oral seperti berlemak merupakan sensasi yang dirasakan dengan terdeteksinya asam lemak bebas. Mattes (2011) menyatakan bahwa terdapat dua tahap dari proses mekanisme sensasi berlemak dapat dirasakan. Pertama, trigliserida (lemak) mengalami proses hidrolisis menjadi gliserol dan asam lemak melalui interaksi salivari lipase. Salivari lipase merupakan enzim yang disekresikan kelenjar von Ebner di lidah. Sal- 
ivari lipase pada manusia umumnya berbeda dengan lipase pada mamalia dimana salivari lipase pada manusia bersifat hidrofobik dan mampu memasuki globula lemak yang kemudian menghdirolisis rantai trigliserida menjadi asam lemak bebas (Chen, 2015). Asam lemak kemudian dideteksi melalui sejumlah mekanisme tertentu meliputi jaringan delayed-rectifiying potassium, reseptor G protein-couples (GPCR120) dan reseptor glikoprotein CD36 (Khan dan Besnard, 2009).

\section{Atribut Tekstur Kekenyalan}

Kekenyalan merupakan karakteristik sekunder tekstur suatu bahan pangan (Andrae-Nightingale et al., 2009). Kekenyalan secara sensori didefinisikan sebagai energi yang diperlukan untuk menghancurkan suatu bahan pangan yang bersifat semi solid ke suatu kondisi siap untuk ditelan (Szczesniak, 2002).

Hasil analisa sensori tekstur cokelat dengan menggunakan metode discrete time intensity dan parameter-parameter dari kurva TI pada atribut tekstur kelengketan cokelat dan disajikan pada Tabel 5 dan Gambar 4. Grafik intensitas tingkat kekenyalan cokelat menunjukkan bentuk kurva yang mengalami penurunan. Intensitas kekenyalan yang tertinggi pada semua sampel diperoleh pada detik ke-30 yaitu pada perlakuan $100 \%$ biji kakao fermentasi Jember dengan lama conching 8 jam yaitu 11.9 dan tingkat kekenyalan terus mengalami penurunan penurunan sampai dengan detik ke-180. Terjadinya penurunan tingkat kekenyalan menunjukkan energi yang diperlukan untuk menghancurkan cokelat menjadi semakin kecil. Semakin kecilnya energi yang diperlukan disebabkan oleh cokelat yang telah meleleh selama dikonsumsi. Cokelat yang telah meleleh menyebabkan perubahan bentuk cokelat menjadi ukuran yang semakin kecil sehingga energi yang diperlukan untuk mengubah cokelat menjadi suatu kondisi siap untuk ditelan menjadi kecil. Perubahan bentuk cokelat disebabkan oleh lemak kakao sebagai fase kontinyu akan mulai meleleh disebabkan temperatur atau panas tubuh. Proses cokelat meleleh di dalam mulut disebabkan karakteristik lemak sebagai fase kontinyu (Ziegler et al., 2001). Temperatur yang berhubungan dengan proses transisi seperti pelelehan akan merubah struktur suatu bahan pangan selama proses pengunyahan karena selama proses ini suhu akan memulai proses modi- fikasi makanan yang mana akan mengubah persepsi tekstur selama proses oral (Pascua et al., 2013).

\section{SIMPULAN}

Analisa sensoris cokelat menunjukkan bahwa intensitas kekerasan yang tertinggi diperoleh pada perlakuan 100\% biji kakao fermentasi Jember dengan lama conching 8 jam yaitu 12.6 pada detik ke-30, , intensitas kekompakan tertinggi yaitu pada perlakuan $50 \%$ biji kakao fermentasi Sulawesi Tenggara $+50 \%$ biji kakao nonfermentasi Sulawesi Tenggara dengan lama conching 8 jam yaitu 12.4 pada detik ke-30 dan intensitas kelengketan yang tertinggi yaitu pada perlakuan 100\% biji kakao fermentasi Jember dengan lama conching 4 jam yaitu 5.9 pada detik ke 120 dan dan kekenyalan tertinggi yaitu pada perlakuan $100 \%$ biji kakao fermentasi Jember dengan lama conching 8 jam yaitu 11.9 pada detik ke-30

\section{DAFTAR PUSTAKA}

Afoakwa, EO. 2010. Chocolate Science and Technology. John Wiley \& Sons, England

Afoakwa, E, O, Paterson, A, Fowler, M. 2007. Factor influencing rheological and textural qualities in chocolate - a review. Trends in Food Science \& Technology. 18(6):290-298

Andrae-Nightingale, L, M, Lee, S, Y, Engeseth, N, J. 2009. Textural changes in chocolate characterized by instrumental and sensory techniques. Journal of Texture Studies. 40(4):427-444

Ariyanti, N, S, Bos, M, M, Kartawinata, K, Tjitrosoedirdjo, S, S, Guhardja, E, Gradstein, S, R. 2008. Bryophytes on tree trunks in natural forests, selectively logged forests and cacao agroforests in central sulawesi, indonesia. Biological Conservation. 141(10):2516-2527

Belščak-Cvitanović, A, Komes, D, Dujmović, M, Karlović, S, Biškić, M, Brnčić, M, Ježek, D. 2015. Physical, bioactive and sensory quality parameters of reduced 
sugar chocolates formulated with natural sweeteners as sucrose alternatives. Food Chemistry. 167:61-70

Bornhorst, G, M, Hivert, H, Singh, R, P. 2014. Rice bolus texture changes due to a-amylase. LWT-Food Science and Technology. 55(1):27-33

Brighenti, M, Govindasamy-Lucey, S, Lim, K, Nelson, K, Lucey, J, A. 2008. Characterization of the rheological, textural and sensory properties of samples of commercial US cream cheese with different fat contents. J. Dairy Sci. 91(12):4501-4517

Cadena, R, S, Bolini, H, M, A. 2011. Time-intensity analysis and acceptance test for traditional and light vanilla ice cream. Food Research International. 44(3):677683

Chale-Rush, A, Burgess, J, R, Mattes, R, D. 2007. Multiple routes of chemo-sensitivity to free fatty acids in humans. Am. J. Physiol. Gastrointest Liver Physiol. 292(5):1206-1212

Chen, J. 2015. Food oral processing: mechanism and implications of food oral destruction. Trends in Food Science and Technology. 45(2):222-228

Davit, M, J, Yusuf, R, P, Yudari, D, A, S. 2013. Pengaruh cara pengolahan kakao fermentasi dan non fermentasi terhadap kualitas, harga jual produk pada unit usaha produktif (UUP) tunjung sari, kabupaten tabanan. E-Jurnal Agribisnis dan Agrowisata. 2(4):191-203

de Morais, E, C, Cruz, A, G, Bolini, H, M, A. 2013. Gluten-free bread: multiple timeintensity analysis, physical characterisation and acceptance test. International Journal of Food Science \& Technology. 48(10):2176-2184

de Ávila, M, D, R, Cambero, M, I, Ordóñez, J, A, de la Hoz, L, Herrero, A, M. 2014. Rheological behaviour of commercial cooked meat products evaluated by tensile test and texture profile analysis (TPA). Meat Science. 98(2):310-315

Kementerian Pertanian. 2013. Peningkatan produksi, produktivitas dan mutu tanaman rempah dan penyegar. Dilihat 20 Agustus 2017. <http:// ditjenbun.pertanian.go.id/downlot. php? file=Pedoman $\%$ 20Teknis $\% 20$ Koordinasi\%20Kegiatan\%20Pengembangan $\% 20$ Tanaman $\% 20$ Rempah $\% 20$ dan $\% 20$ Penyegar.pdf>
Fernandez V, A, Müller, A, J, Sandoval A, J. 2013. Thermal, structural and rheological of dark chocolate with different composition. Journal Food Engineering. 116(1):97-108

Gaikwad, V. 2012. Oral Processing of Dark Chocolate. Tesis. The Riddet Institute, Massey University. New Zealand

Gu, F, Tan, L, Wu, H, Fang, Y, Xu, F, Chu, Z, Wang, Q. 2013. Comparison of cocoa beans from china, indonesia and papua new guinea. Foods. 2(2):183-197

Ishihara, S, Nakauma, M, Funami, T, Odake, S, Nishinari, K. 2011. Swallowing profiles of food polysaccharide gels in relation to bolus rheology. Food Hydrocolloids. 25(5):1016-1024

Jovanovic, O, L, Pajin, B, S. 2002. Sensory and instrumental evaluation of physical characteristics of laboratory - made chocolate. Dilihat 25 September 2017. $<$ http://agris.fao.org/agris-search/ search.do?recordID=YU2003000725>

Khan, N, A, Besnard, P. 2009. Oro-sensory perception of dietary lipids: new insights into the fat taste transduction. Biochim Biophys Acta. 1791(3):149-155

Kikuchi, T, Michiwaki, Y, Koshizuka, S, Kamiya, T, Toyama, Y. 2017. Numerical simulation of interaction between organs and food bolus during swallowing and aspiration. Computers in Biology and Medicine. 80:114-123

Lada, Y, G, Supriyanto, Darmadji, P. 2014. Pengaruh perendaman biji kakao kering dan bahan alat sangrai terhadap sifat fisik dan profil senyawa volatil kakao sangrai serta sifat sensoris cokelat batang yang dihasilkan. AGRITECH. 34(4):439-447

Lee, S, Heuberger, M, Rousset, P, Spencer, N, D. 2002. Chocolate a sliding interface. Journal of Food Science. 67(7):2712-2716

Lorido, L, Estévez, M, Ventanas, S. 2014. A novel approach to asses temporal sensory perception of muscle foods: application of a time-intensity techniques to diverse iberian meat products. Meat Sci. 96(1):385-393

Mattes, R, D. 2011. Oral fatty acid signaling and intestinal lipid processing: support and supposition. Physiol Behav. 105(1):27-35

Menezes, A, G, T, Batista, N, N, Ramos C, L, Andrade e Silva, A, R, Efraim, P, Pinheiro, A, C, M, Schwan R, F. 2016. 
Investigation of chocolate produced from four different brazilian varieties of cocoa (Theobroma cacao L.) inoculated with Saccharomyces cerivisiae. Food Research International. 81:83-90

Moraes, P, C, B, T, Bolini, H, M, A. 2010. Different sweeteners in beverages prepared with instant and roasted ground coffee: Ideal and equivalent sweetness. Journal of Sensory Studies. 25(1):1-11

Morais, E, C, Pinheiro, A, C, M, Nunes, C, A, Bolini, H, M, A. 2014. Multiple timeintensity analysis and temporal dominance of sensations of chocolate dairy dessert using prebiotic and different high-intensity sweeteners. Journal of Sensory Studies. 29(5):339-350

Munarso, S, J. 2016. Penanganan pascapanen untuk peningkatan mutu dan daya saing komoditas kakao. Jurnal Litbang Pertanian. 33(3):111-120

Novianti, AL. 2015. Profile Time Intensity Pemanis Alami DCPC (Deionized Clarified Pineapple Concentrate) dari Hasil Samping Pengolahan Nenas. Skripsi. IPB. Bogor

Palazzo, A, B, Bolini, H, M, A. 2014. Multiple time-intensity analysis: sweetness, bitterness, chocolate flavor and melting rate of chocolate with sucralose, rebaudioside and neotame. Journal of Sensory Studies. 29(1):21-32

Palazzo A, B, Carvalho M, A, R, Efraim, P, Bolini, H, M, A. 2011. The determination of isosweetness concentrations of sucralose, rebaudioside and neotame as sucrose substitutes in new diet chocolate formulations using the time intensity analysis. Journal of Sensory Studies. 26(4):291-297

Pascua, Y, Koç, H, Foegeding, E, A. 2013. Food structure: roles of mechanical properties and oral processing in determining sensory texture of soft materials. Current Opinion in Colloid and Interface Science. 18(4):324-333

Paula, A, M, Conti-Silva, A, C. 2014. Texture profile and correlation between sensory and instrumental analyses on extruded snacks. Journal of Food Engineering. 121:9-14

Peyron, M, A, Gierczynski, I, Hartman, C, Loret, C, Dardevet, D, Martin, N, Woda, A. 2011. Role of physical bolus properties as sensory input In the trigger of swallowing. PLoS ONE. 6(6):e21167
Peyvieux, C, Dijksterhuis, G. 2001. Training a sensory panel for TI: a case study. Food Quality and Preference. 12(1):19-28

Pionnier, E, Nicklaus, S, Chabanet, C, Mioche, L, Taylor, A, J, Le Quéré, J, L, Salles, C. 2004. Flavor perception of a model cheese: relationships with oral and physic-chemical parameters. Food Quality and Preference. 15(7-8):843-852

Poppenborg, P, Hölscher, D. 2009. The influence of emergent trees on rainfall distribution in a cacao agroforest (sulawesi, indonesia). Flora - Morphology, Distribution, Functional Ecology of Plants. 204(10):730-736

Rizo, A, Peña, E, Alarcon-Rojo, A, D, Fiszman, S, Tarrega, A. 2018. Relating texture perception of cooked ham to the bolus evolution in the mouth. Food Research International

Rubiyo, Siswanto. 2012. Peningkatan produksi dan pengembangan kakao (Theobroma cacao L.) di indonesia. Buletin RISTRI. 3(1):33-48

Sanchez, L, Perez, MD. 2012. ‘Physical Properties of Dairy Products'. Dalam I Arana (ed.). Physical Properties of Foods: Novel Measurement Techniques and Application. CRC Press, Florida

Shah, A, B, Jones, G, P, Vasiljevic, T. 2010. Sucrose-free chocolate sweetened with Stevia rebaudiana extract and containing different bulking agents-effect on physicochemical and sensory properties. International Journal of Food Science and Technology. 45:1426-1435

Suwastika, I, N, Muslimin, Rifka, Aisyah, N, Rahmansyah, Mutmainah, Ishizaki, Y, Basri, Z, Shiina, T. 2015. Genotyping based on SSR marker on local cacao (Theobroma Cacao L.) from central sulawesi. Procedia Environmental Sciences. 28:88-91

Szczesniak, A, S. 2002. Texture is a sensory property. Food Quality and Preference. 13(4):215-225

Torres-Moreno, M, Torrescasana, E, SalasSalvadó, J, Blanch, C. 2015. Nutritional composition and fatty acids profile in cocoa beans and chocolate with different geographical origin and processing conditions. Food Chemistry. 166:125-132

Wu, D, Sun, D, W, He, Y. 2014. Novel noninvasive distribution measurement of texture profile analysis (TPA) in salmon fillet by using visible and near 
Jurnal Teknologi Pertanian Vol. 19 No. 1 [April 2018] 1-14

Pengaruh Asal Biji Kakao dan Lama Conching Terhadap Karakteristik Sensori [Azhar dkk]

infrared hyperspectral imaging. Food Chemistry. 145:417-426

Yoshimine, M, Nagatomi, H, Miura, H, Tanaka, Y, Arai, I. 2008. Analysis of the mechanical properties of food bolus masticated by denture weares. J. Med Dent Sci. 55(3-4):227-246
Ziegler, G, R, Mongia, G, Hollender, R. 2001. The role of particle size distribution of suspended solids in defining the sensory properties of milk chocolate. International Journal of Food Properties. 4(2):353-370 